\title{
Metabolic cooperation in oral microbial communities during growth on mucin
}

\author{
D. J. Bradshaw, ${ }^{1}$ K. A. Homer, ${ }^{2}$ P. D. Marsh' and D. Beighton ${ }^{2}$
}

Author for correspondence: D. Beighton. Tel: +4471346 3608. Fax: +44713463624.

\footnotetext{
1 Research Division, Centre for Applied Microbiology and Research (CAMR), Porton Down, Salisbury SP4 OJG, UK

2 Oral Microbiology, Royal College of Surgeons Department of Dental Sciences, King's College School of Medicine and Dentistry, Faculty of Clinical Dentistry, Caldecot Road, Denmark Hill, London SE5 9RW, UK
}

\begin{abstract}
Hog gastric mucin has been used as a model glycoprotein to determine the role of particular glycosidases produced by different oral bacteria in the development of stable, diverse microbial communities. The patterns of glycosidase and protease activity were determined in pure cultures of ten representative species of oral bacteria using synthetic substrates. A fivemember mixed culture was established in a chemostat, comprising species with minimal glycosidase and protease activity, in which hog gastric mucin was the major carbon and energy source. Introduction of additional species with novel enzyme activities (e.g. sialidase, $\alpha$-fucosidase and endopeptidase) led to their establishment within the community to make communities with seven, eight, nine and ten members and resulted in an increase in the total viable counts of the microbial consortium. This increase in viable count was made up of the numbers of the newly added species as well as from a rise in the numbers of the existing community members. This result suggested that glycoprotein catabolism involved the synergistic and concerted action of several species with overlapping patterns of enzyme activity. Such metabolic cooperation results in the liberation of additional nutrients, and this may help to maintain the characteristic diversity of resident microbial communities found in many natural habitats.
\end{abstract}

Keywords: dental plaque, bacterial communities, chemostat, glycosidase, mucin

\section{INTRODUCTION}

The growth of bacteria in the oral cavity involves the degradation of host-derived glycoproteins (including salivary mucins) and proteins (Beckers \& van der Hoeven, 1982; Beighton \& Hayday, 1986; Beighton et al., 1986). The particular glycosidic enzymes produced include sialidase, $\beta$-galactosidase, $\beta$ - $N$-acetylglucosaminidase, $\beta$ $N$-acetylgalactosaminidase, $\alpha$ - and $\beta$-mannosidase and $\alpha$ fucosidase (Kilian et al., 1989; Beighton et al., 1991; Slots, 1981). These enzymes can catalyse hydrolysis of the oligosaccharide sidechains and the liberation of carbohydrates which are thus made available to the resident microflora for growth. Additionally, removal of the oligosaccharide sidechains increases the proteolytic susceptibility of the protein core (Gottschalk \& Fazekas de St Groth, 1960; Sharon \& Lis, 1982), which can thus be degraded by a wide range of bacterial exo- and endoproteolytic enzyme activities to release peptides and amino acids which may then be utilized. The effect of these

Abbreviations: HGM, hog gastric mucin; 4-MU, 4-methylumbelliferyl; AMC, 7-amido-4-methylcoumarin. bacterial activities is that the growth rate of bacteria in dental plaque can be sustained even in the absence of host diet (Beckers \& van der Hoeven, 1982; Beighton \& Hayday, 1986; Beighton et al., 1986). Withdrawal of the host diet leads to significant increases in the plaque levels of these specific glycosidic and non-specific proteolytic enzyme activities (Smith \& Beighton, 1986, 1987).

In order to study the role of the resident microflora in the catabolism of complex, endogenous molecules, hog gastric mucin (HGM) (Beighton et al., 1988; Glenister et al., 1988; Bradshaw et al., 1989) or heat-inactivated human serum (ter Steeg et al., 1988) have been used as model substrates. When pooled dental plaque was used as the inoculum in continuous culture studies these substrates were found to support complex microbial communities of plaque bacteria (Beighton et al., 1988; Glenister et al., 1988; Bradshaw et al., 1989; ter Steeg et al., 1988). In such studies, bacterial growth was accompanied by the production of degradative enzyme activities and by the utilization of the added glycoproteins. However, the use of complex, poorly defined inocula did not readily enable the role of particular species to be established. Batch 
culture studies have demonstrated that simple combinations of certain species of dental plaque bacteria degrade proteins and glycoproteins synergistically (Gharbia et al., 1989; van der Hoeven \& Camp, 1991; Homer \& Beighton, 1992).

The aim of the present study, therefore, was to investigate further the role of particular enzymes produced by members of the resident oral flora in (i) the persistence of individual species, and (ii) the development and stability of oral microbial communities, when growing on complex macromolecules. These studies were performed by establishing increasingly diverse (but defined) mixed cultures of oral bacteria in a chemostat in which HGM was the main carbon and energy source. HGM was used as the model substrate because it shows the highest similarity in oligosaccharide structure with human salivary mucin (Herp et al., 1979).

\section{METHODS}

Bacterial strains. The bacteria used in this study were Streptococcus mutans R9, Streptococcus oralis EF186, Streptococcus gordonii NCTC 7865, Neisseria subflava A1078, Veillonella dispar ATCC 17745, Lactobacillus casei AC413, Actinomyces naeslundii (formerly Actinomyces viscosus, Johnson et al., 1990) WVU 627, Porphyromonas gingivalis W50, Prevotella nigrescens T588 (formerly P. intermedia, Shah \& Gharbia, 1992) and Fusobacterium nucleatum ATCC 10953. These species were chosen on the basis of their relevance in oral microbial ecology, and for their ease of identification (McKee et al., 1985). They were maintained and stored as previously described (Bradshaw et al., 1989).

Growth of bacteria in batch culture. The production of glycosidases by the above bacteria was determined by culturing each strain, in duplicate batch culture, in complex medium (modified BM; McKee et al., 1985) diluted 1:5 (BM/5) but supplemented with $0.25 \%$ HGM (Sigma). The final composition of the medium was thus (g per l distilled water): HGM, 2.5 ; proteose peptone (Oxoid), 2; yeast extract (Difco), 1; cysteine. $\mathrm{HCl}$ (Sigma), 0.1; haemin (Sigma), 0.001. The $\mathrm{pH}$ was adjusted to $7 \cdot 4$ prior to autoclaving. When bacteria were grown in pure culture in BM/ 5 without HGM, growth was insufficient for enzyme analysis. After appropriate incubation $(3 \mathrm{~d}$ aerobically for N. subflava, $4 \mathrm{~d}$ anaerobically for $L$. casei, A. naeslundii and all the streptococcal species, and $6 \mathrm{~d}$ anaerobically for Por. gingivalis, Pre. nigrescens, F. nucleatum and $V$. dispar), cells were harvested by centrifugation. Supernatants were decanted and stored at $-20^{\circ} \mathrm{C}$, as were the bacterial pellets. All cell pellets and culture supernatants were assayed for specific glycosidic and proteolytic enzyme activities.

Measurement of bacterial enzyme activities. Glycosidic and proteolytic enzyme activities were measured using fluorogenic substrates essentially as previously described (Homer et al., 1992). Briefly, specific glycosidase activities were determined using 4-MU-linked substrates (4-MU- $\alpha$-L-fucoside, 4-MU- $\alpha-N$ acetylneuraminate, 4-MU- $N$-acetyl- $\beta$-D-glucosaminide, 4-MU$\beta$-D-mannoside, 4-MU- $\beta$-D-galactoside, $4-\mathrm{MU}-N$-acetyl- $\beta$-Dgalactosaminide) while proteolytic activities were monitored using glycyl-prolyl-AMC and benzoyl-arginyl-AMC as model substrates. Bacterial cell pellets were thawed at ambient temperature and resuspended in $50 \mathrm{mM}$ TES buffer, $\mathrm{pH} 7 \cdot 5$. Enzyme assays were set up in clear, flat-bottomed microtitre trays, using $50 \mu \mathrm{l}$ substrate solutions $\left(100 \mu \mathrm{g} \mathrm{ml}^{-1}\right)$ in TES buffer, $50 \mu \mathrm{l}$ TES buffer and $100 \mu \mathrm{l}$ cell suspension or culture supernatant. The TES buffer was supplemented with $4 \mathrm{mM}$ dithiothreitol for assays with the anaerobic bacteria. All assays were performed in duplicate and incubated anaerobically at $37^{\circ} \mathrm{C}$. Control assays contained TES buffer in place of bacterial suspensions or culture supernatants. Relative fluorescence values were read at intervals over $5 \mathrm{~h}$ on a fluorimeter fitted with a plate reading attachment (LS-3B, Perkin-Elmer) at excitation and emission wavelengths of $380 \mathrm{~nm}$ and $460 \mathrm{~nm}$, respectively. Product formation was estimated by comparison of fluorescence values with standard curves of either 4methylumbelliferone or 7-amido-4-methylcoumarin. The protein concentration of bacterial cell suspensions was estimated after extraction with $0.5 \mathrm{M} \mathrm{NaOH}$ with the Coomassie Blue dyebinding assay (Sigma) using bovine serum albumin (Sigma) as the standard. Specific enzyme activities were expressed as $\mathrm{nmol} \mathrm{h}^{-1}$ (mg protein) ${ }^{-1}$ or as $\mathrm{nmol} \mathrm{h}^{-1}$ (ml supernatant) $)^{-1}$.

Chemostat growth of mixed bacterial communities. Increasingly diverse bacterial communities were grown in a chemostat as described previously (Bradshaw et al., 1989). The chemostat growth medium was $\mathrm{BM} / 5$ supplemented with $0.25 \% \mathrm{HGM}$; the $\mathrm{pH}$ and temperature were maintained automatically at $7 \cdot 0 \pm 0 \cdot 1$ and $37^{\circ} \mathrm{C}$, respectively, and the dilution rate $(D)$ was $0 \cdot 1 \mathrm{~h}^{-1}$ (equivalent to a mean generation time of $6.9 \mathrm{~h}$ ). The working volume was $500 \mathrm{ml}$, and the gas phase was $5 \% \mathrm{CO}_{2}$ in $\mathrm{N}_{2}$ (Distillers).

Initially a five-species community was established in the chemostat by inoculating the culture with a pooled inoculum consisting of $S$. mutans R9, $S$. gordonii NCTC 7865, N. subflava A1078, V. dispar ATCC 17745, and F. nucleatum ATCC 10953. These organisms were selected as they constitute commonly isolated members of the normal plaque microflora but which, with the exception of $S$. gordonii, do not produce detectable glycosidase activities relevant to the degradation of the oligosaccharide side chains of HGM. A steady state was allowed to establish ( $5 \mathrm{~d}$ at $\left.D=0 \cdot 1 \mathrm{~h}^{-1}\right)$ and culture samples were taken for microbiological analysis.

In order to introduce sialidase activity, $S$. oralis EF186 and $A$. naeslundii WVU 627 were inoculated into the five-species community to establish a seven-species culture. A new steady state was established and samples were removed for microbiological analysis. An eight-species community was established with the addition of L. casei AC413, which had $\alpha$-fucosidase activity, and appropriate culture samples were again taken. The complexity of the community was then further increased by the addition of Por. gingivalis W50 (with high endopeptidase activity and the ability to degrade benzoyl-arginyl-AMC) to form a ninespecies community. The most diverse community, a ten-species community, was achieved by the addition of Pre. nigrescens T588 (with moderate endopeptidase activity as judged by glycylprolyl-AMC hydrolysis and unable to hydrolyse benzoylarginyl-AMC). A new steady state was achieved before samples were taken for viable counts.

Enumeration of bacteria in chemostat samples. Individual bacterial species in samples taken from the chemostat were enumerated by decimal dilution of the culture and plating aliquots on a range of selective and non-selective culture media as described previously (Bradshaw et al., 1989). Mutiple samples were taken during each steady state. The detection limits for the species were 10 c.f.u. $\mathrm{ml}^{-1}$ for $A$. naeslundii, N. subflava and $L$. casei; $10^{2}$ c.f.u. $\mathrm{ml}^{-1}$ for Pre. nigrescens, $S$. gordonii and $S$. mutans; $10^{3}$ c.f.u. $\mathrm{ml}^{-1}$ for $F$. nucleatum; $10^{4}$ c.f.u. $\mathrm{ml}^{-1}$ for $V$. dispar and S. oralis; and $10^{5}$ c.f.u. $\mathrm{ml}^{-1}$ for Por. gingivalis. The total number of bacteria in each steady-state community and the individual bacterial counts were expressed as $\log _{10}$ (c.f.u. $\mathrm{ml}^{-1}$ ), and the mean \pm standard deviation (SD) of individual counts for each 
Table 1. Production of selected glycosidases and proteases by individual bacteria grown in batch culture (BM/5 + mucin medium)

\begin{tabular}{|c|c|c|c|c|c|c|}
\hline \multirow[t]{2}{*}{ Species } & \multicolumn{6}{|c|}{ Enzyme activity [nmol substrate hydrolysed $h^{-1}(\mathrm{mg} \text { protein })^{-1}$ ] } \\
\hline & Sialidase & $\begin{array}{c}\text { N-Acetyl- } \\
\text { glucosaminidase }\end{array}$ & $\beta$-Galactosidase & $\alpha$-Fucosidase & $\begin{array}{c}\text { Gly-Pro } \\
\text { diamino } \\
\text { peptidase }\end{array}$ & $\begin{array}{c}\text { Trypsin- } \\
\text { like } \\
\text { activity* }\end{array}$ \\
\hline S. mutans & ND & ND & ND & ND & 747 & ND \\
\hline S. gordonii & ND & 566 & 36 & 50 & 11000 & 0.7 \\
\hline N. subflava & ND & ND & ND & ND & ND & ND \\
\hline$V$. dispar & ND & 2 & ND & ND & ND & ND \\
\hline F. nucleatum & ND & 33 & ND & ND & ND & ND \\
\hline S. oralis & 10900 & 300 & ND & ND & 13900 & ND \\
\hline A. naeslundii & 260 & ND & 17 & ND & ND & ND \\
\hline L. casei & ND & 14 & ND & 2453 & 495 & ND \\
\hline Por. gingivalis & 8 & ND & ND & ND & 216 & 1552 \\
\hline Pre. nigrescens & ND & 20 & ND & 507 & 405 & ND \\
\hline
\end{tabular}

ND, Not detected (insignificant enzyme activity).

* Trypsin-like activity measured by hydrolysis of benzoyl-Arg-AMC substrate.

Table 2. Growth of various defined mixed communities of oral bacteria on mucinsupplemented medium

\begin{tabular}{|c|c|c|c|c|c|}
\hline \multirow[t]{2}{*}{ Species } & \multicolumn{5}{|c|}{ Mean $\log _{10}$ (c.f.u. $\left.\mathrm{ml}^{-1}\right) \pm$ SD $(n)$} \\
\hline & Mixed 5 & Mixed 7 & Mixed 8 & Mixed 9 & Mixed 10 \\
\hline S. mutans & $4.03 \pm 0.51(5)$ & $4.61 \pm 0.23(5)$ & $4.55 \pm 0.57(4)$ & $4 \cdot 93 \pm 0 \cdot 13(3)$ & $4.84 \pm 0.08(2)$ \\
\hline S. gordonii & $7 \cdot 32 \pm 0.20(5)$ & $7 \cdot 54 \pm 0 \cdot 12(5)$ & $7 \cdot 80 \pm 0.05(4)$ & $7 \cdot 93 \pm 0.09(3)$ & $7 \cdot 91 \pm 0 \cdot 03(2)$ \\
\hline N. subflava & $3 \cdot 50 \pm 0 \cdot 16$ & $4.73 \pm 0.40(5)$ & $5 \cdot 60 \pm 0.29(4)$ & $5 \cdot 73 \pm 0 \cdot 23(3)$ & $5 \cdot 82 \pm 1 \cdot 10(2)$ \\
\hline$V$. dispar & $5.94 \pm 0.61$ & $6.61 \pm 0.28$ & $7 \cdot 43 \pm 0 \cdot 10$ & $7.59 \pm 0.06(3)$ & $7 \cdot 46 \pm 0 \cdot 17(2)$ \\
\hline F. nucleatum & $7 \cdot 75 \pm 0 \cdot 12(5)$ & $7 \cdot 74 \pm 0.28(5)$ & $7 \cdot 52 \pm 0 \cdot 15(4)$ & $7 \cdot 77 \pm 0 \cdot 13(3)$ & $7 \cdot 56 \pm 0.67(2)$ \\
\hline S. oralis & - & $6.38 \pm 0.62(5)$ & $7 \cdot 00 \pm 0 \cdot 20(4)$ & $6.85 \pm 0.33$ & $7 \cdot 10 \pm 0 \cdot 08(2)$ \\
\hline A. naeslundii & - & $5 \cdot 98 \pm 0.33(5)$ & $5 \cdot 27 \pm 0 \cdot 48(4)$ & $5 \cdot 10 \pm 0 \cdot 17(3)$ & $4.78 \pm 0.09(2)$ \\
\hline L. casei & - & - & $5 \cdot 23 \pm 0 \cdot 15(4)$ & $5 \cdot 60 \pm 0 \cdot 30(3)$ & $5.89 \pm 0.41(2)$ \\
\hline Por. gingivalis & - & - & - & $7 \cdot 72 \pm 0.06(3)$ & $7 \cdot 63 \pm 0.28(2)$ \\
\hline Pre. nigrescens & - & - & - & - & $7.02 \pm 0.03(2)$ \\
\hline Total & $7.91 \pm 0.09(5)$ & $8 \cdot 02 \pm 0 \cdot 15(5)$ & $8.13 \pm 0.64(4)$ & $8.39 \pm 0.05(3)$ & $8 \cdot 37 \pm 0 \cdot 20(2)$ \\
\hline
\end{tabular}

steady-state community were calculated. Mean values were compared initially by ANOVA, and then by pair-wise comparisons of the steady-state communities, which were made using the Scheffe multiple comparison test (Statgraphics) with $P<0.05$ accepted as the level of significance.

\section{RESULTS}

\section{Enzyme activities of individual species in batch culture}

The enzyme activities of each of the species grown in pure culture are summarized in Table 1. Individual species varied markedly in their range of glycosidic and endopeptidase activities. No single species produced all of the enzymes assayed for.

Consideration of these data enabled defined mixed cultures to be constructed with precise patterns of glycosidase and protease activities. Thus, the bacterial species selected for the initial bacterial community possessed minimal $\beta$-galactosidase and $\alpha$-fucosidase activity and no sialidase activity, thereby limiting its ability to catabolize HGM (Table 1). The addition of $S$. oralis and $A$. naeslundii to form a seven-species community would result in the 


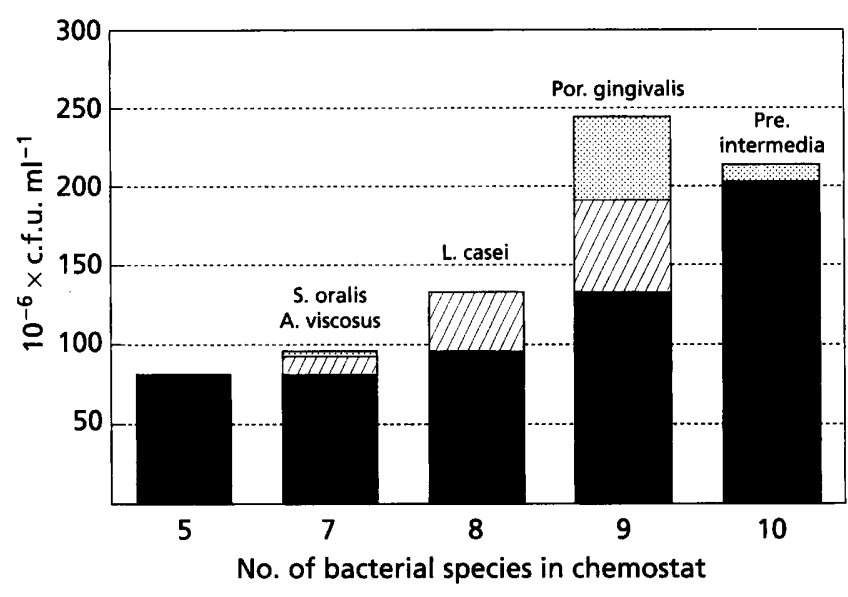

Fig. 1. Total viable count of microbial communities as their diversity is increased. The figure shows the numerical contribution of the added species and their effect on the levels of the extant bacterial species. $\square$, Extant $(5,7,8,9)$; 四, increase in extant; 圈, newly added.

introduction of organisms with a marked capacity to produce sialidase. The addition of $L$. casei to form an eight-species community would markedly increase the production of $\alpha$-fucosidase activity, while the introduction of Por. gingivalis to form a nine-species community substantially increased the total endopeptidase activity of the community. The inoculation of Pre. nigrescens would not introduce any novel enzyme activities as determined from this range of substrates.

\section{Bacterial population dynamics of defined mixed cultures}

The five-species community reached a steady state in the chemostat. Stable steady-state communities were also attained following the addition of species to make mixed cultures with seven, eight, nine and ten members (Table 2 ). The total viable count of the steady-state mixed cultures increased significantly $(P<0.001)$ from $7.91 \pm$ 0.05 in the five-species community to $8.40 \pm 0.07$ in the nine-species community; there was a small, non-significant reduction to $8.37 \pm 0.08$ in the ten-species community (Table 2). Fig. 1 shows that the increase in the numbers of bacteria is a combination of an increase in the numbers of bacteria in the extant community plus a contribution from the newly added species.

The overall effect on the levels of individual species as the diversity of the community increased is shown in Table 2. Viable counts of $N$. subflava and $V$. dispar increased markedly, particularly when the diversity of the community increased from five to eight species. The levels of other species such as $S$. mutans, $S$. gordonii and L. case $i$ also rose, but to a lesser degree. In contrast, the mean viable counts of $F$. nucleatum and $S$. oralis remained relatively constant within microbial communities of increasing diversity; this was also observed with Por. gingivalis.

\section{DISCUSSION}

The growth of bacteria in the oral cavity is primarily dependent upon the ability of dental plaque bacteria to utilize endogenous nutrients, especially glycoproteins, including salivary mucins. Observations in rats (Beckers \& van der Hoeven, 1982) and macaque monkeys (Beighton \& Hayday, 1986; Beighton et al., 1986) have shown that withdrawal of the diet, but not drinking water, for short periods does not significantly alter the rate of bacterial growth in dental plaque. Likewise, fasted laboratory animals (Kilian \& Rolla, 1976) accumulate dental plaque with a similar microbial composition to that formed during conventional feeding. Bacteria may liberate nutrients for growth from the oligosaccharide sidechains of glycoproteins, from peptides derived from the protein core of glycoproteins, and from non-glycosylated proteins, by the action of specific glycosidases and nonspecific proteases, respectively. Changes in the levels of these enzyme activities can be measured in dental plaque of monkeys receiving different dietary regimens (Beighton \& Smith, 1986; Smith \& Beighton, 1986, 1987).

In laboratory studies using simple and defined mixtures of bacteria, combinations of $S$. mutans and Streptococcus sobrinus with either, or both, $A$. naeslundii and $F$. nucleatum degraded human transferrin and bovine serum albumin synergistically (Homer \& Beighton, 1992) while Por. gingivalis in combination with $F$. nucleatum hydrolysed casein synergistically (Gharbia et al., 1989) and mixtures of $S$. oralis and $S$. sanguis degraded HGM synergistically (van der Hoeven \& Camp, 1991). Chemostat studies using complex microbial communities derived from pooled dental plaque have indicated that the degradation of serum proteins is accomplished by the synergistic and concerted action of various bacteria; different stable bacterial populations were also found to exhibit the same metabolic capabilities (ter Steeg et al., 1988).

In the present study, HGM has been used as a model glycoprotein as its oligosaccharide structure is similar to that of many human glycoproteins (Herp et al., 1979). The carbohydrates in the side chains of mucin-type (O-linked) glycoproteins are primarily sialic acid, galactose, $N$ acetylglucosamine and fucose and are linked via either serine or threonine to the protein core. These carbohydrates are present in different combinations, though sialic acid and fucose are always terminal and galactose and $N$-acetylglucosamine are $\beta$-linked. Mannose, present in $N$-linked oligosaccharide side-chains, may be either $\alpha$ or $\beta$-linked (Herp et al., 1979). The diversity of these sidechains and of the protein core result in a complex molecule whose degradation will result only from the action of several bacterial enzymes. The actions of the enzymes produced by individual species results in the liberation of nutrients from different regions of the macromolecule. Perhaps such large molecules may be considered to possess an array of discrete 'nutrient niches', each of which may be exploited by a limited number of species. A consortium of bacteria is necessary, therefore, to maximize the nutritional exploitation of such a complex substrate, as has been proposed for the human colon (Hoskins et al., 
1985). Sugars released during the breakdown of these glycoproteins can support the growth of non-mucindegrading species (Hoskins et al., 1992).

In the present study, a five-species community was able to establish in the chemostat and reach a steady state. Subsequently, further steady states were achieved when additional species were introduced. Implicit in this observation is that microbial interactions are occurring (Veldkamp, 1976), and/or the growth of the component species was not being limited by the same nutrient (Alexander, 1971; Pirt, 1975). Further, in each steadystate community a given species might be limited by a different nutrient. The total number of bacteria (c.f.u. $\mathrm{ml}^{-1}$ ) rose significantly as the species diversity increased, especially from the five-species community to the nine-species community. However, there was no significant increase in bacterial numbers upon the addition of Pre. nigrescens to the nine-species community, confirming that the introduction of this species was not accompanied by the addition of any novel degradative abilities. The order in which the bacteria were introduced may influence the steady-state community structures, as we were unable to introduce successfully Pre. nigrescens into the five-species community (data not shown).

The rise in viable count of the community as the species diversity was increased was not due simply to the numbers of added cells. Generally, there was a greater contribution due to the increase in numbers of some existing members of the community. Thus, the introduction of further degradative enzyme activities not only enabled the newly added species to establish within the existing microbial community but, in doing so, also provided additional substrates for growth and further catabolic opportunities for species within the pre-existing populations.

There appeared to be three types of microbial response as the diversity of the community increased step-wise. Firstly, there was an increase in the numbers of the preexisting members of the community for the reasons described above (although $V$. dispar may also increase in numbers due to the elevated levels of lactate arising from the metabolism of the HGM-derived carbohydrates by other species). Secondly, there were certain species, especially $F$. nucleatum, which remained at a constant level throughout the changes to the species diversity of the community. This implies that the metabolism of these species was not markedly influenced by other organisms. This may be because they neither co-operate nor compete with other members of this model community, i.e. their metabolic niche or domain does not coincide or overlap appreciably with those of the other species in the present consortium. This is supported by some observations of cultures grown in the absence of HGM, in which $F$. nucleatum predominated, indicating that it depended largely upon the peptide components of the medium for its success in the culture (unpublished observations). Thirdly, the consistent loss of $A$. naeslundii with each stepwise addition of other species implied that competition could occur between the new and existing members of the community. The observation that $A$. naeslundii was not totally displaced from the community underlines the diversity of nutritional niches that are presented to bacteria by macromolecules as complex as glycoproteins.

In conclusion, this study has confirmed that HGM can support the growth of diverse bacterial communities. The degradation of glycoproteins involves the synergistic and concerted action of several species which possess complementary patterns of glycosidase and protease activities. The metabolism of such molecules is one mechanism by which the stability and diversity of microbial communities, characteristic of many natural environments, may be maintained.

Alexander, M. (1971). Nutrition. In Microbial Ecology, pp. 94-125. New York: Wiley.

Beckers, H. J. A. \& van der Hoeven, J. S. (1982). Growth rates of Actinomyces viscosus and Streptococcus mutans during early colonization of tooth surfaces in gnotobiotic rats. Infect Immun 35, 583-587.

Beighton, D. \& Hayday, H. (1986). The influence of diet on the growth of streptococcal bacteria on the molar teeth of monkeys (Macaca fascicularis). Arch Oral Biol 31, 449-454.

Beighton, D. \& Smith, K. (1986). The modulation of exoglycosidic enzymes in the supragingival plaque of macaque monkeys. FEMS Microbiol Lett 34, 319-322.

Beighton, D., Smith, K. \& Hayday, H. (1986). The growth of bacteria and the production of exoglycosidic enzymes in the dental plaque of macaque monkeys. Arch Oral Biol 31, 829-835.

Beighton, D., Smith, K., Glenister, D. A., Salamon, K. E. \& Keevil, C. W. (1988). Increased degradative enzyme production by complex communities of dental plaque bacteria in mucin-limited continuous culture. Microb Ecol Health Dis 1, 85-94.

Beighton, D., Hardie, J. M. \& Whiley, R. A. (1991). A scheme for the identification of viridans streptococci. $J$ Med Microbiol 35, 367-372.

Bradshaw, D. J., McKee, A. S. \& Marsh, P. D. (1989). Effects of carbohydrate pulses and $\mathrm{pH}$ on population shifts within oral microbial communities in vitro. J Dent Res 68, 1298-1302.

Gharbia, S. E., Shah, H. N. \& Welch, S. G. (1989). The influence of peptides on the uptake of amino acids in Fusobacterium; predicted interactions with Porpbyromonas gingivalis. Curr Microbiol 19, 231235.

Glenister, D. A., Salamon, K. E., Smith, K., Beighton, D. \& Keevil, C. W. (1988). Enhanced growth of complex communities of dental plaque bacteria in mucin-limited continuous culture. Microb Ecol Health Dis 1, 31-38.

Gottschalk, A. \& Fazekas de St Groth, S. (1960). Studies on mucoproteins III. The accessibility to trypsin of the susceptible bonds in ovine submaxillary gland mucoprotein. Biochem Biopbys Acta 43, 513-519.

Herp, A., Wu, A. M. \& Moschera, J. (1979). Current concepts of the structure and nature of mammalian salivary mucous glycoproteins. Mol Cell Biochem 23, 27-44.

Homer, K. A. \& Beighton, D. (1992). Synergistic degradation of transferrin by mutans streptococci in association with other dental plaque bacteria. Microb Ecol Health Dis 5, 111-116.

Homer, K. A., Manji, F. \& Beighton, D. (1992). Inhibition of peptidase and glycosidase activities of Porphyromonas (Bacteroides) gingivalis, Bacteroides intermedius and Treponema denticola by plant extracts. J Clin Periodontol 19, 305-310.

Hoskins, L. C., Agustines, M., McKee, W. B., Boulding, E. T., 
Kriaris, M. \& Niedermeyer, G. (1985). Mucin degradation in human colon ecosystems. Isolation and properties of fecal strains that degrade $\mathrm{ABH}$ blood group antigens and oligosaccharides from mucin glycoproteins. J Clin Invest 75, 944-953.

Hoskins, L. C., Boulding, E. T., Gerker, T. A., Harouny, V. R. \& Kriaris, M. S. (1992). Mucin glycoprotein degradation by mucin oligosaccharide-degrading strains of human faecal bacteria. Characterisation of saccharide cleavage products and their potential role in the nutritional support of larger faecal populations. Microb Ecol Health Dis 5, 193-207.

Johnson, J. L., Moore, L. V. H., Kaneko, B. \& Moore, W. E. C. (1990). Actinomyces georgiae sp. nov., Actinomyces gerencseriae sp. nov., designation of two genospecies of Actinomyces naeslundii, and inclusion of $A$. naeslundii serotypes II and III and Actinomyces viscosus serotype II in $A$. naeslundii genospecies 2. Int J Syst Bacteriol 40, 273-286.

Kilian, M. \& Rölla, G. (1976). Initial colonization of teeth in monkeys as related to diet. Infect Immun 14, 1022-1027.

Kilian, M., Mikkelson, L. \& Henrichsen, J. (1989). Taxonomic study of viridans streptococci: description of Streptococcus gordonii sp. nov. and amended descriptions of Streptococcus sanguis (White and Niven, 1946), Streptococcus oralis (Bridges and Sneath, 1982), and Streptococcus mitis (Andrewes and Horder, 1906). Int J Syst Bacteriol 39, 471-484.

McKee, A. S., McDermid, A. S., Ellwood, D. C. \& Marsh, P. D. (1985). The establishment of reproducible, complex communities of oral bacteria in the chemostat using defined innocula. $J A p p l$ Bacteriol 59, 263-275.

Pirt, S. J. (1975). Mixed cultures. In Principles of Microbial and Cell Cultivation, pp. 199-210. Oxford: Blackwell Scientific Publications.
Shah, H. \& Gharbia, S. E. (1992). Biochemical and chemical studies on strains designated Prevotella intermedia and proposal of a new pigmented species, Prevotella nigrescens sp. nov. Int J Syst Bacteriol 42, 542-546.

Sharon, N. \& Lis, H. (1982). Glycoproteins. In The Proteins, vol. V, pp. 1-144. Edited by H. Neurath \& R. L. Hill. London: Academic Press.

Slots, J. (1981). Enzymatic characterization of some oral and nonoral gram-negative bacteria with the API ZYM system. J Clin Microbiol 14, 288-294.

Smith, K. \& Beighton, D. (1986). The effect of the availability of diet on exoglycosidase production by supragingival plaque of macaque monkeys. J Dent Res 65, 1349-1352.

Smith, K. \& Beighton, D. (1987). Proteolytic enzymes in the supragingival plaque of macaque monkeys. Arch Oral Biol 32, 473-476.

ter Steeg, P. F., van der Hoeven, J.S., de Jong, M. H., van Munster, P. J. J. \& Jansen, M. J. H. (1988). Modelling the gingival pocket by enrichment of subgingival microflora in human serum in chemostats. Microb Ecol Health Dis 1, 73-84.

Veldkamp, H. (1976). Mixed culture studies with the chemostat. In Continuous Culture 6: Applications and New Fields, pp. 315-328. Edited by A. C. R. Dean, D. C. Ellwood, C. G. T. Evans \& J. Melling. Chichester: Ellis Horwood.

van der Hoeven, J. S. \& Camp, P. J. M. (1991). Synergistic degradation of mucin by Streptococcus oralis and Streptococcus sanguis in mixed chemostat cultures. J Dent Res 70, 1041-1044.

Received 5 May 1994; revised 8 July 1994; accepted 9 August 1994. 